\title{
Impact of Water Deprivation and Rehydration on Blood Parameters of Sheep under Middle Gujarat Agro-Climatic Condition
}

\author{
R. P. Patel ${ }^{1}$, M. M. Islam ${ }^{1}$, N. P. Sarvaiya ${ }^{2}$ and K. N. Wadhwani ${ }^{1}$ \\ ${ }^{1}$ Department of Livestock Production Management, ${ }^{2}$ Reproductive Biology Research Unit, \\ College of Veterinary Science and Animal Husbandry, Anand Agricultural University, \\ Anand-388001, Gujarat (INDIA) \\ *Corresponding author
}

\section{A B S T R A C T}

\section{Keywords}

Water deprivation, rehydration, blood parameter, hoggets

\section{Article Info}

Accepted:

12 May 2020

Available Online:

10 June 2020

Present study was conducted on eighteen farm born adult hoggets (25-30 kg) of Patanwadi and Marwari breeds to study the effect of water restriction (WR) and rehydration on blood parameters. The experimental animals were randomly divided in to three treatment groups based on body weight comprising of six animals in each treatment viz. $\mathrm{T}_{1}$ : Control (ad lib water- three time), $\mathrm{T}_{2}$ : $\left(\mathrm{WR}_{1}-12 \mathrm{hrs}\right.$ watering interval- two time), $\mathrm{T}_{3}$ : $\left(\mathrm{WR}_{2}-24 \mathrm{hrs}\right.$ watering interval- one time). The duration of experiment was 44 days. The experimental animals either offered water thrice or once, did not produce any significant effect on $\mathrm{Hb}(\mathrm{g} / \mathrm{dL})$ and PCV (\%). The Urea $(\mathrm{mg} / \mathrm{dL})$, uric acid $(\mathrm{mg} / \mathrm{dL})$ and creatinine $(\mathrm{mg} / \mathrm{dL})$ concentration significantly $(\mathrm{P}<0.05)$ increased when animals exposed to restricted watering in $\mathrm{T}_{2}$ and $\mathrm{T}_{3}$ as compared to $\mathrm{T}_{1}$ group. Sodium level increased non-significantly when animals were kept on twice a day than once a day watering frequency but level increased significantly $(\mathrm{P}<0.05)$ when animal kept on thrice a day than once. Potassium level did not influence by any level of water frequency while chloride level significantly $(\mathrm{P}<0.05)$ influenced by treatment. The Triiodothyronine $(\mathrm{ng} / \mathrm{ml})$, Thyroxin (ng/ml) and cortisol (ng/ml) level remained at par either animals kept on once, twice or thrice a day watering frequencies. However, cortisol hormone level in $12 \mathrm{hrs}$ WR and $24 \mathrm{hrs}$ WR remained higher than $a d$ lib water offered to animal groups. It may be concluded from the present study that hoggets should be watered at least twice daily and at less than twelve hours' interval.

\section{Introduction}

Dehydration in warm weather conditions reduces plasma volume as water is taken up by the tissue (Schaefer et al., 1990). Increased PCV $(\%)$ and $\mathrm{Hb}(\mathrm{g} \%)$ concentration are good indicators of dehydration. The water deprivation raised blood biochemical constituents. High values obtained in waterdeprived ewes showed signs of haemo- concentration caused by dehydration. The transfer function of the kidney is altered under water stress with slower glomerular filtration and higher urea re-absorption (Kataria and Kataria, 2007).

Increase in secretion of the hormone arginine vasopressin is observed which is released from hypothalamus in response to dehydration and it increases permeability of 
collecting duct of kidneys and there by promote urea reabsorption in the kidneys and reduced the loss of urea concentration (Meintjes and Engelbrecht, 1999). The cortisol could be a good indicator in accessing acute stress response in small ruminants but not chronic stress such as dehydration, also reported that, cortisol level did not return to normal level even after 72 hours of rehydration (El- Nouty et al., 1991).

\section{Materials and Methods}

Present study was conducted at Livestock Farm Complex, Department of Livestock Production Management, College of Veterinary Science and Animal Husbandry, Anand Agricultural University, Anand. The present experiment was conducted for 44 days' duration (42 days' water deprivation +2 days' rehydration) in hot dry season ( $1^{\text {st }}$ May to $13^{\text {th }}$ June). Farm born eighteen adult hoggets (25-30 kg) of Patanwadi and Marwari sheep were selected as experimental animals and randomly divided in to three treatment groups on the basis of body weight comprising of six animals in each treatment viz. $\mathrm{T}_{1}$ : Control (ad lib water- three time), $\mathrm{T}_{2}$ : ( $\mathrm{WR}_{1}-12$ hrs watering interval- two time), $\mathrm{T}_{3}$ : ( $\mathrm{WR}_{2}-24 \mathrm{hrs}$ watering interval- one time). The experimental animals were maintained on ICAR feeding standard (1998) and wholesome clean drinking water were offered. In $\mathrm{T}_{1}$ group, animals were offered water daily at. 9.00 a.m., 3.00 p.m., and 9.00 p.m. where as in $\mathrm{T}_{2}$ daily at 9.00 a.m. and 9.00 p.m. and in $\mathrm{T}_{3}$ daily at 9.00 a.m. only. The tub containing measured quantity of water was placed in front of animals for $30 \mathrm{~min}$. The blood samples were collected from the jugular vein in vacutainer with anticoagulant. The fresh whole blood was used to estimate hematological parameters like $\mathrm{Hb}$, PCV using Automated blood cell counter (Mindray-BC2800VET) and remaining blood was used to separate plasma which was used to estimate various biochemical parameters like T3 (Triiodothyronine), T4 (Thyroxin) and Cortisol using Radio Immune Assay (RIA) kit with Gamma- counter. Plasma Creatinine and Uric acid was estimated using Chemistry analyzer (BS-120) while Sodium and Potassium was analyzed using Flame Photometer-128. Plasma Urea and Chloride were analyzed manually by readymade available KIT.

\section{Statistical analysis}

The experimental data of dehydration were analyzed by completely randomized design by individual analyses (Snedecore and Cochran, 1985). All the rehydration data were analyzed by one-way ANOVA.

\section{Results and Discussion}

Results of influence of water frequency and rehydration on blood parameters of hoggets are presented in Table 1 and 2, respectively. The experimental animals either offered water thrice or once, did not produce any significant effect on $\mathrm{Hb}(\mathrm{g} / \mathrm{dL})$. The values observed under $T_{2}$ and $T_{3}$ was higher than $T_{1}$. The rehydration of experimental animals did not produce any significant change in $\mathrm{Hb}(\mathrm{g} / \mathrm{dL})$ level. The PCV (\%) did not alter by the level of water frequency indicated watering once in a day is sufficient to maintain PCV (\%) and there is no development of haemoconcentration. However, PCV (\%) in the animals of $T_{2}$ and $T_{3}$ showed higher values than the animals of control group. The PCV (\%) recovered non significantly due to rehydration in $\mathrm{T}_{2}(17.14 \%)$ and $\mathrm{T}_{3}(26.23 \%)$ on $2^{\text {nd }}$ day of rehydration. Jaber et al., (2004) studied the effect of water restriction on certain physiological parameters in Awassi sheep and reported that PCV and hemoglobin showed no significant variation within and among treatments which supports the present findings. 
$\mathrm{Hb}$ in Sheep and Goats neither influenced by dehydration nor by seasons as per the study of Khanvilkar (2014) which again supports the result of present study. The Urea level increased significantly $(\mathrm{P}<0.05)$ to the tune of 46.72 and $52.52 \%$ when animals were exposed to twice $\left(\mathrm{T}_{2}\right)$ and once $\left(\mathrm{T}_{3}\right)$ daily watering frequency, respectively as compared to ad lib. watering. Blood urea $(\mathrm{mg} / \mathrm{dL})$ concentration of experimental animals dropped down non significantly due to rehydration and could not reach to normal value even after two days' ad lib. watering. The water deprivation was associated with significant $(\mathrm{P}<0.05)$ increase in serum urea $(\mathrm{mg} / \mathrm{dL})$ concentration as reported by Kheir and Ahmed (2008); Abdelatif et al., (2010); Gupta (2013) and Patel (2015) which supports the present findings.

The uric acid concentration increased significantly $(\mathrm{P}<0.05)$ by 26.66 and $21.33 \%$ when animals were offered water after 12 and $24 \mathrm{hrs}$, respectively as compared to animals of control group. Uric acid concentration drops down significantly $(\mathrm{P}<0.05)$ by 37.50 and $48.40 \%$ in $\mathrm{T}_{3}$ after 24 and $48 \mathrm{hrs}$ of rehydration, respectively. The creatinine concentration increased significantly $(\mathrm{P}<0.05)$ by 15.69 and $18.59 \%$ when animals were offered water after 12 and $24 \mathrm{hrs}$, respectively as compared to animals of control group. The creatinine concentration did not normalise in spite of $48 \mathrm{hrs}$ of rehydration. Basheir et al., (2009) and Khanvilkar (2014) reported significant $(\mathrm{P}<0.05)$ rise in Uric acid $(\mathrm{mg} / \mathrm{dl})$ and creatinine $(\mathrm{mg} \%)$ concentration due to water deprivation supported the present findings.

The sodium level increased non-significantly when animals were kept on twice $(2.84 \%)$ a day and increased significantly $(\mathrm{P}<0.05)$ when kept on thrice $(7.18 \%)$ a day watering frequency. Potassium level was not affected by any level of watering frequency in present study. The Chloride level significantly $(\mathrm{P}<0.05)$ increased by treatment in $\mathrm{T}_{2}(9.57$ $\%)$ and $\mathrm{T}_{3}(19.02 \%)$ animal groups as compared to control group.

Table.1 Influence of water frequency on blood parameters of hoggets

\begin{tabular}{|c|c|c|c|}
\hline Blood Parameters & T1 (Control) & T2 (12 hr WR) & T3 (24 hr WR) \\
\hline Haemoglobin (g/dL) & $8.56 \pm 0.06$ & $8.73 \pm 0.16$ & $9.01 \pm 0.09$ \\
\hline PCV (\%) & $28.41 \pm 0.21$ & $28.75 \pm 0.42$ & $29.55 \pm 0.23$ \\
\hline Urea (mg/dL) & $24.85^{\mathrm{a}} \pm 0.51$ & $36.46^{\mathrm{b}} \pm 1.78$ & $37.90^{\mathrm{b}} \pm 2.01$ \\
\hline Uric acid (mg/dL) & $0.75^{\mathrm{a}} \pm 0.06$ & $0.95^{\mathrm{bc}} \pm 0.07$ & $0.91^{\mathrm{b}} \pm 0.11$ \\
\hline Creatinine (mg/dL) & $1.53^{\mathrm{a}} \pm 0.03$ & $1.77^{\mathrm{b}} \pm 0.06$ & $1.82^{\mathrm{b}} \pm 0.05$ \\
\hline Sodium (mmol/L) & $144.36^{\mathrm{a}} \pm 0.39$ & $148.47^{\mathrm{ac}} \pm 1.68$ & $154.73^{\mathrm{bc} \pm 3.09}$ \\
\hline Potassium (mmol/L) & $3.98 \pm 0.12$ & $4.04 \pm 0.10$ & $4.07 \pm 0.04$ \\
\hline Chloride (mmol/L) & $101.03^{\mathrm{a}} \pm 0.63$ & $110.70^{\mathrm{b}} \pm 03.72$ & $120.24^{\mathrm{c}} \pm 6.34$ \\
\hline Triiodothyronine (T) $\mathbf{m})(\mathbf{n g} / \mathbf{m l})$ & $1.33 \pm 0.14$ & $1.30 \pm 0.18$ & $1.39 \pm 0.16$ \\
\hline Thyroxin $\left(\mathbf{T}_{\mathbf{4}}\right)(\mathbf{n g} / \mathbf{m l})$ & $42.62 \pm 0.23$ & $46.42 \pm 0.35$ & $45.95 \pm 0.38$ \\
\hline Cortisol $(\mathbf{n g} / \mathbf{m l})$ & $47.36 \pm 00.46$ & $59.07 \pm 04.99$ & $56.61 \pm 04.41$ \\
\hline
\end{tabular}

Means with dissimilar superscripts $(a, b, c)$ in a row differ significantly $(\mathrm{P}<0.05)$ 
Table.2 Influence of water rehydration (RH) on blood parameters of hoggets

\begin{tabular}{|c|c|c|c|c|}
\hline Blood Parameters & Days & T1 (Control) & $\begin{array}{c}\text { T2 } \\
(12 \mathrm{hr} \text { WR })\end{array}$ & $\begin{array}{c}\text { T3 } \\
(24 \mathrm{hr} \mathrm{WR})\end{array}$ \\
\hline \multirow[t]{3}{*}{ Haemoglobin (g/dL) } & Final Day (DH) & $8.58 \pm 0.34$ & $8.65 \pm 0.38$ & $9.06 \pm 0.43$ \\
\hline & $1^{\text {st }}$ Day (RH) & $8.53 \pm 0.33$ & $8.43 \pm 0.22$ & $9.15 \pm 0.49$ \\
\hline & $2^{\text {nd }}$ Day (RH) & $8.30 \pm 0.16$ & $8.23 \pm 0.18$ & $8.45 \pm 0.28$ \\
\hline \multirow[t]{3}{*}{$\operatorname{PCV}(\%)$} & Final Day (DH) & $28.81 \pm 1.12$ & $28.76 \pm 1.05$ & $30.05 \pm 1.18$ \\
\hline & $1^{\text {st }}$ Day $(\mathrm{RH})$ & $28.18 \pm 1.18$ & $28.10 \pm 0.40$ & $30.06 \pm 1.50$ \\
\hline & $2^{\text {nd }}$ Day $(\mathrm{RH})$ & $28.05 \pm 0.59$ & $27.71 \pm 0.42$ & $28.40 \pm 0.84$ \\
\hline \multirow[t]{3}{*}{ Urea $(\mathrm{mg} / \mathrm{dL})$} & Final Day (DH) & $25.98 \pm 2.08$ & $43.27 \pm 2.48$ & $44.63 \pm 3.35$ \\
\hline & $1^{\mathrm{st}}$ Day $(\mathrm{RH})$ & $25.30 \pm 2.00$ & $41.35 \pm 2.09$ & $43.50 \pm 3.19$ \\
\hline & $2^{\text {nd }}$ Day $(\mathrm{RH})$ & $24.52 \pm 1.81$ & $40.34 \pm 2.31$ & $40.22 \pm 2.70$ \\
\hline \multirow[t]{3}{*}{ Uric acid (mg/dL) } & Final Day (DH) & $0.85 \pm 0.11$ & $1.13 \pm 0.23$ & $1.28^{\mathrm{b}} \pm 0.14$ \\
\hline & $1^{\text {st }}$ Day $(\mathrm{RH})$ & $0.55 \pm 0.12$ & $0.85 \pm 0.12$ & $0.80^{\mathrm{a}} \pm 0.08$ \\
\hline & $2^{\text {nd }}$ Day (RH) & $0.49 \pm 0.10$ & $0.64 \pm 0.10$ & $0.66^{\mathrm{a}} \pm 0.09$ \\
\hline \multirow[t]{3}{*}{ Creatinine (mg/dL) } & Final Day (DH) & $1.61 \pm 0.06$ & $1.98 \pm 0.08$ & $1.96 \pm 0.07$ \\
\hline & $1^{\text {st }}$ Day $(\mathrm{RH})$ & $1.60 \pm 0.05$ & $1.87 \pm 0.05$ & $1.92 \pm 0.05$ \\
\hline & $2^{\text {nd }}$ Day $(\mathrm{RH})$ & $1.59 \pm 0.05$ & $1.79 \pm 0.06$ & $1.88 \pm 0.06$ \\
\hline \multirow[t]{3}{*}{ Sodium (mmol/L) } & Final Day (DH) & $144.30 \pm 6.85$ & $156.90 \pm 2.78$ & $162.90 \pm 4.23$ \\
\hline & $1^{\text {st }}$ Day $(\mathrm{RH})$ & $143.40 \pm 5.06$ & $155.40 \pm 5.43$ & $163.80 \pm 4.01$ \\
\hline & $2^{\text {nd }}$ Day $(\mathrm{RH})$ & $144.00 \pm 7.61$ & $155.10 \pm 2.56$ & $159.60 \pm 3.38$ \\
\hline \multirow[t]{3}{*}{ Potassium (mmol/L) } & Final Day (DH) & $4.27 \pm 0.13$ & $4.60 \pm 0.16$ & $4.21 \pm 0.18$ \\
\hline & $1^{\text {st }}$ Day $(\mathrm{RH})$ & $4.05 \pm 0.09$ & $4.42 \pm 0.12$ & $4.14 \pm 0.20$ \\
\hline & $2^{\text {nd }}$ Day $(\mathrm{RH})$ & $3.82 \pm 0.16$ & $4.25 \pm 0.10$ & $4.06 \pm 0.17$ \\
\hline \multirow[t]{3}{*}{ Chloride (mmol/L) } & Final Day (DH) & $101.59 \pm 1.45$ & $123.43 \pm 7.35$ & $141.37^{\mathrm{a}} \pm 5.95$ \\
\hline & $1^{\text {st }}$ Day $(\mathrm{RH})$ & $100.59 \pm 3.08$ & $121.91 \pm 5.89$ & $130.87^{\mathrm{a}} \pm 6.32$ \\
\hline & $2^{\text {nd }}$ Day $(\mathrm{RH})$ & $100.40 \pm 2.55$ & $109.36 \pm 1.90$ & $120.18^{b} \pm 6.93$ \\
\hline \multirow{3}{*}{$\begin{array}{l}\text { Triiodothyronine }\left(\mathbf{T}_{\mathbf{3}}\right) \\
(\mathrm{ng} / \mathrm{ml})\end{array}$} & Final Day (DH) & $0.71^{\mathrm{a}} \pm 0.07$ & $0.95^{\mathrm{a}} \pm 0.07$ & $0.62^{\mathrm{a}} \pm 0.09$ \\
\hline & $1^{\text {st }}$ Day $(\mathrm{RH})$ & $1.36^{\mathrm{b}} \pm 0.06$ & $1.34^{b} \pm 0.09$ & $1.77^{b} \pm 0.12$ \\
\hline & $2^{\text {nd }}$ Day $(\mathrm{RH})$ & $1.70^{c} \pm 0.07$ & $1.55^{\mathrm{b}} \pm 0.14$ & $1.80^{\mathrm{b}} \pm 0.08$ \\
\hline \multirow[t]{3}{*}{ Thyroxin $\left(\mathbf{T}_{4}\right)(\mathrm{ng} / \mathrm{ml})$} & Final Day (DH) & $42.21 \pm 6.14$ & $47.39 \pm 5.58$ & $46.36 \pm 5.99$ \\
\hline & $1^{\text {st }}$ Day $(\mathrm{RH})$ & $42.08 \pm 2.46$ & $46.10 \pm 4.29$ & $46.36 \pm 5.25$ \\
\hline & $2^{\text {nd }}$ Day $(\mathrm{RH})$ & $41.31 \pm 4.64$ & $45.19 \pm 9.58$ & $46.49 \pm 5.49$ \\
\hline \multirow[t]{3}{*}{ Cortisol (ng/ml) } & Final Day (DH) & $48.87 \pm 3.33$ & $76.62 \pm 11.57$ & $76.62 \pm 17.44$ \\
\hline & $1^{\text {st }}$ Day $(\mathrm{RH})$ & $46.45 \pm 3.15$ & $68.78 \pm 6.54$ & $75.41 \pm 22.63$ \\
\hline & $2^{\text {nd }}$ Day $(\mathrm{RH})$ & $44.04 \pm 5.40$ & $64.55 \pm 18.13$ & $65.76 \pm 14.93$ \\
\hline
\end{tabular}

Means with dissimilar superscripts $(a, b, c)$ in a column within same parameter differ significantly $(\mathrm{P}<0.05)$ 
After $48 \mathrm{hrs}$ of rehydration, the chloride decrease significantly $(\mathrm{P}<0.05)$ in $\mathrm{T}_{3}$. The effect of rehydration was non-significant on sodium and potassium level. As per the study of Igbokwe (1993), Potassium level was not affected but Sodium and Chloride level increased by water deprivation which is in accordance of present findings.

Plasma minerals $(\mathrm{Na}+, \mathrm{K}+$ and $\mathrm{Ca}++)$ levels were not affected by either water or feed restrictions or feed in the study of Kheir and Ahmed (2008) which again support the results of present study.

The Triiodothyronine (ng/ml) and Thyroxin (ng/ml) remained at par either animals kept on once, twice or thrice daily watering frequencies. These observations were in agreement with the findings of other workers (Gupta, 2013 and Patel, 2015). Similarly, the cortisol $(\mathrm{ng} / \mathrm{ml})$ level remained at par either animals kept on once, twice or thrice daily watering frequencies. However, the cortisol level of $T_{3}$ and $T_{2}$ group remained higher as compared to $\mathrm{T}_{1}$ group.

Triiodothyronine level increased significantly $(\mathrm{P}<0.05)$ under twice and once a day watering in hot dry season on 1st day (41.05 and $185 \%$ ) but on 2 nd day (15.67 and 1.7\%) increased non-significantly of rehydration indicated $24 \mathrm{hrs}$ of rehydration is sufficient to bring out T3 hormone level normal. There was no effect of rehydration on $\mathrm{T}_{4}$ and cortisol hormone level.

It may be concluded from the present study that hoggets should be watered at least twice daily and at less than twelve hours' interval to maintain sodium and chloride level. Water should not be withheld for more than $12 \mathrm{hrs}$ to maintain Urea, Uric acid and creatinine level in the blood of sheep. Watering Once daily is sufficient to maintain the $\mathrm{Hb}$ and PCV level in the blood.

\section{References}

Abdelatif, A. M., El sayed, S. A. and Hassan, Y. M. 2010. Effect of state of hydration on body weight, blood constituents and urine excretion in Nubian Goats (Capra hircus). World J. Agric. Sci., 6(2): 178188.

Basheir, R. A., Omer, S. A. and Mohamed, O. S. A. 2009. The effect of twenty-four hours water deprivation on renal function of Sudanese Nubian goats. $J$. Sc. Tech., 10(1): 1-7.

El-Nouty, F.D., El-Naggar, M.I., Hassan, G.A and Salem, M.H. 1991. Effect of lactation on water requirements and metabolism in Egyptian sheep and goats. World Review of Animal Production; XXVI: 40- 43.

Gupta, Neelam, 2013. Performance of indigenous sheep under water restriction and rehydration in Middle Gujarat Agroclimatic condition. Thesis presented to Anand Agriculture University, Anand, (Gujarat State).

ICAR. 1998. Nutrient requirements of Livestock and Poultry. Indian Council of Agric. Res. New Delhi, India.

Igbokwe, I. O. 1993. Haemoconcentration in Yankasa sheep exposed to prolonged water deprivation. Small Ruminant Research, 12(1), 99-105.

Jaber, L.S., Habre, A., Rawda, N., Abid Said, M., Barbour, E.K and Hamdeh, S. 2004. The effect of water restriction on certain physiological parameters in Awassi sheep. Small Ruminant Research. 54(12):115-120

Kataria, N. and Kataria, A. K. 2007. Compartmental water management of Marwari sheep during dehydration and rehydration. Veterinarski Arhiv., 77(6): 551-559.

Khanvilkar, A. V. 2014. Effect of Water Restriction and Rehydration on Sheep and Goats under Middle Gujarat 
Agroclimatic Condition. Thesis presented to Anand Agriculture University, Anand, (Gujarat State).

Kheir, I. M. and Ahmed, M. M. M. 2008. Effects of water and feed restriction on some physiological and haematological parameters and blood constituents of Sudanese desert goats fed high and low quality forages under semi-arid conditions. Indian J. Anim. Res., 42(1): 39-43.

Meintjes, R. A. and Engelbrecht, H. 1999. The effect of an angiotensin-converting enzyme inhibitor on water and electrolyte balance in water-restricted sheep. J. S. Afr. Vet. Assoc., 70(4):14750.
Patel, N. R. 2015. Performance of indigenous sheep under water restriction and rehydration in Agroclimatic condition of middle Gujarat. Thesis presented to Anand Agriculture University, Anand, (Gujarat State).

Schaefer, A. L., Jones S.D., Tong, A.K.W., Lepage, P and Murray NL. 1990. The effects of withholding feed and water on selective blood metabolites in marketweight beef steers. Canadian Journal of Animal Science; 70: 1151-1158.

Snedecor, G. W. and Cochran, W. G. 1985. Statistical methods, $7^{\text {th }}$ edn. The Iowa State University Press, Ames. Iowa, USA.

\section{How to cite this article:}

Patel. R. P., M. M. Islam, N. P. Sarvaiya and Wadhwani. K. N. 2020. Impact of Water Deprivation and Rehydration on Blood Parameters of Sheep under Middle Gujarat AgroClimatic Condition. Int.J.Curr.Microbiol.App.Sci. 9(06): 104-109. doi: https://doi.org/10.20546/ijcmas.2020.906.013 